\author{
Magdalena Zadworna-Cieślak* \\ Nina Ogińska-Bulik** \\ * Instytut Badań Społecznych, Społeczna Akademia Nauk w Łodzi \\ ** Instytut Psychologii, Uniwersytet Łódzki
}

\title{
Osobowość typu D i poczucie koherencji a podejmowanie zachowań zdrowotnych przez młodzież
}

\section{Wprowadzenie}

Problematyka zdrowego stylu życia w ostatnich latach coraz częściej jest przedmiotem badań $\mathrm{w}$ różnych obszarach nauki, a ważną przyczyną tego stanu jest zapotrzebowanie społeczne i wzrost świadomości zdrowotnej. Na gruncie psychologii zdrowia prowadzi się $\mathrm{w}$ tym zakresie przede wszystkim badania uwarunkowań zachowań zdrowotnych. Ich pojęcie nie jest jednoznaczne i ulega zmianom na przestrzeni lat, a w literaturze można znaleźć wielość jego ujęć definicyjnych. Jedno z nich proponuje H. S ę k (2000, s. 539), według której są to „reaktywne, nawykowe i/lub celowe formy aktywności człowieka, które pozostaja - na gruncie wiedzy obiektywnej o zdrowiu i subiektywnego przekonania - w istotnym, wzajemnym związku ze zdrowiem". To właśnie związek ze zdrowiem czyni omawianą problematykę tak istotną społecznie. Zachowania antyzdrowotne pełnią wiodącą rolę w powstawaniu chorób, co skutkuje także wzrostem umieralności, a zachowania korzystne dla zdrowia mogą je ochraniać i zapobiegać zaburzeniom (por. Gniazdowski, 1990). W ślad za badaniami naukowymi idą $w$ ostatnich latach praktyczne oddziaływania nastawione na krzewienie zdrowego stylu życia - szczególnie wśród młodych pokoleń. Niestety, obraz zachowań związanych ze zdrowiem w grupach polskiej młodzieży pozostawia wiele do życzenia. $\mathrm{Z}$ jednej strony wskazuje się na znaczne niedostatki $\mathrm{w}$ zakresie prozdrowotnych zachowań, a z drugiej - na częste podejmowanie zachowań ryzykownych. Skłania to do poszukiwania czynników je determinujących, a także stawiania pytań o skuteczność dotychczasowych oddziaływań profilaktycznych (por. Kolbows ka, 2008; Mazur i in., 2007; Oblacińska, Woynarowska (red.), 2006; Si ęrosławski, 2007).

Nawyki związane ze zdrowiem, zarówno prozdrowotne, jak i antyzdrowotne, podlegają kształtowaniu od najwcześniejszych lat w toku socjalizacji i uczenia się. Czynnikiem warunkującym ich rozwój w okresie dzieciństwa jest przede 
wszystkim środowisko rodzinne, a następnie środowisko szkolne i rówieśnicze. W późniejszym okresie podejmowanie zachowań związanych ze zdrowiem uwarunkowane jest głównie osobistymi decyzjami poszczególnych osób. Stąd istotna rola zmiennych podmiotowych, a przede wszystkim właściwości osobowości jednostki, w tym jej przekonań i oczekiwań dotyczących samej siebie i otaczającego świata. Przegląd badań w zakresie uwarunkowań zachowań zdrowotnych (Do 1 iń s k a-Z y g m un t, 2001; Ł u s z c z yń s ka, 2004; Og iń ska-Bulik, 2010; O gińska-Bulik, Juczyński, 2008/2010; Zadworna-Ci eślak, Ogińska-Bulik, 2011; Zi arko, 2006) wskazuje, że z zachowaniami tymi korelują: poczucie własnej skuteczności, optymizm życiowy, poczucie koherencji, wartościowanie zdrowia oraz - w mniejszym stopniu wewnętrzne umiejscowienie kontroli zdrowia i samoocena, której niski poziom sprzyja podejmowaniu zachowań ryzykownych.

G. Larsson i in. (za: P a sikowski, 2000), analizując dane uzyskane od 5 tys. respondentów, wykazał istnienie pozytywnej zależności między poczuciem koherencji a zachowaniami zdrowotnymi, subiektywną oceną zdrowia i jakością życia. Badania $\mathrm{w}$ grupie dorastających także potwierdziły występowanie związku poczucia koherencji $\mathrm{z}$ deklarowaną tendencją do zachowań prozdrowotnych (Z a dworna-Cieślak, Gutowska-Wyka, 2009) W badaniach młodych dorosłych poczucie koherencji (przede wszystkim wymiar poczucia sensowności i zaradności) było istotnie pozytywnie skorelowane $\mathrm{z}$ intencją do podjęcia zachowania zdrowotnego, a także $\mathrm{z}$ deklarowanymi zachowaniami zdrowotnymi (Z i a r k o, 2006).

Istotną rolę w podejmowaniu zachowań zdrowotnych mogą pełnić wymiary składające się na osobowość stresową (typ D), tj. negatywna emocjonalność i hamowanie społeczne. Negatywna emocjonalność wyraża się w skłonności jednostki do przeżywania silnych negatywnych emocji, takich jak lęk, gniew, irytacja lub wrogość. Z kolei hamowanie społeczne odnosi się do unikania zagrożenia związanego $\mathrm{z}$ relacjami społecznymi i dotyczy skłonności do powstrzymywania się od wyrażania negatywnych emocji i zachowań zgodnych z tymi emocjami. Brak ekspresji emocjonalnej ma charakter świadomy i występuje głównie w sytuacjach społecznych (Denollet, 2005; O gińska-B u lik, 2009; O g iń s k a-B u li k, J u c z y ń s k i, 2008/2010).

Występowanie typu D jest niekorzystne dla zdrowia. Ten typ osobowości jest czynnikiem ryzyka rozwoju chorób somatycznych, głównie sercowonaczyniowych (Denollet，2005; Ogińska-Bulik，2009; Ogińska-B u li k, J u c z y ń sk i, 2008/2010). Sprzyja także angażowaniu się w zachowania ryzykowne dla zdrowia, takie jak nadużywanie alkoholu, palenie tytoniu czy zażywanie środków narkotycznych (przegląd badań - por. Ogińska-Bulik, 2009). Dotychczas nie prowadzono badań w zakresie poszukiwania 
zależności typu $\mathrm{D}$ z zachowaniami prozdrowotnymi, ale można założyć, że współwystępowanie negatywnej emocjonalności i hamowania społecznego nie będzie korzystne z punktu widzenia tych zachowań. Należy jednak zaznaczyć, że osobowość typu D nie musi wprost prowadzić do zaniedbywania zdrowia. Przejawianie niekorzystnych dla zdrowia cech osobowości (negatywna emocjonalność, hamowanie społeczne) może być niwelowane przez inne podmiotowe właściwości jednostki, związane z przekonaniami na temat własnej osoby lub świata zewnętrznego, np. wysokie poczucie koherencji. Oznaczałoby to, że jeśli jednostka ma poczucie, że informacje napływające ze świata są zrozumiałe, że dysponuje zasobami umożliwiającymi jej radzenie sobie z przeciwnościami losu i że są w jej życiu takie obszary, którym warto poświęcać czas i energię, to pomimo występowania negatywnych emocji i utrzymywania dystansu wobec innych ludzi może podejmować zachowania sprzyjające zdrowiu. Poczucie koherencji może być traktowane jako zmienna pośrednicząca w zakresie związku między typem D a zachowaniami zdrowotnymi.

\section{Cel badań}

Celem podjętych badań było ustalenie, czy istnieje związek między osobowością typu D i poczuciem koherencji a podejmowaniem przez młodzież zachowań zdrowotnych. Postawiono następujące pytania badawcze:

- jakie zachowania zdrowotne prezentuje badana młodzież i czy zmienne socjodemograficzne (wiek, płeć, miejsce zamieszkania) różnicują nasilenie tych zachowań?

- czy istnieje związek między wymiarami osobowości typu D i poczuciem koherencji a nasileniem zachowań zdrowotnych?

- które ze zmiennych niezależnych (wymiary osobowości typu D, wymiary poczucia koherencji) są predyktorami zachowań zdrowotnych?

- jaka jest struktura zmiennych niezależnych wpływających na zachowania zdrowotne?

\section{Osoby badane}

Badana grupa obejmowała 211 osób - 96 chłopców i 115 dziewcząt. Wiek badanych mieścił się w zakresie 17-19 lat $(M=18,01 ; S D=0,49)$. Badana młodzież pochodziła z losowo wybranych łódzkich szkół licealnych. 


\section{Zastosowane narzędzia badawcze}

Do pomiaru zmiennych zastosowano:

- Inwentarz Zachowań Zdrowotnych (IZZ) autorstwa Z. J u c z y ń s k i e g o (2001).

Technika zawiera 24 stwierdzenia opisujące różnego typu zachowania związane ze zdrowiem, których nasilenie podlega ocenie na skali od 1 (,prawie nigdy”) do 5 (,prawie zawsze”). Po zsumowaniu częstotliwości występowania poszczególnych zachowań ustala się ogólny wskaźnik zachowań zdrowotnych oraz stopień nasilenia czterech kategorii zachowań - prawidłowych nawyków żywieniowych, zachowań profilaktycznych, praktyk zdrowotnych oraz pozytywnych nastawień psychicznych. Im wyższy/niższy wynik, tym wyższe/niższe nasilenie mierzonych zachowań. Prawidłowe nawyki żywieniowe uwzględniają głównie rodzaj spożywanej żywności (np. pieczywo pełnoziarniste, warzywa i owoce), zachowania profilaktyczne dotyczą przede wszystkim przestrzegania zaleceń zdrowotnych i uzyskiwania informacji o zdrowiu i chorobie, praktyki zdrowotne obejmują nawyki związane ze snem, rekreacją lub aktywnością fizyczną, zaś pozytywne nastawienia psychiczne dotyczą unikania zbyt silnych emocji, napięć i stresów. IZZ jest narzędziem o zadowalających parametrach psychometrycznych.

- Skalę DS-14, autorstwa J. Denolleta, służącą do pomiaru osobowości typu D, polska adaptacja: N. Ogińska-Bulik, Z. Juczyński, J. Denollet (J u c z y ń s k i, O gińs ka-B ulik, 2009).

Narzędzie składa się z 14 pozycji, do których osoba badana ustosunkowuje się, posługując się określeniami „fałszywe” (0), „raczej fałszywe” (1), „trudno powiedzieć” (2), „raczej prawdziwe” (3), „prawdziwe” (4). Wyniki oblicza się oddzielnie dla obydwu wymiarów typu $\mathrm{D}, \mathrm{tj}$. negatywnej emocjonalności oraz hamowania społecznego. Za typ D uznaje się osobę, która w obydwu wymiarach uzyskała wyniki na poziomie co najmniej 10 pkt. Narzędzie charakteryzują dobre właściwości psychometryczne.

- Kwestionariusz Orientacji Życiowej (SOC-29) autorstwa Antonovsky’ego (polska adaptacja: J. K o n i r e k, B. D u d e k, Z. Mak ow sk a, 1993).

Technika służy do oceny poczucia koherencji oraz jego trzech wymiarów: poczucia zrozumiałości, zaradności i sensowności. SOC-29 składa się z 29 stwierdzeń, ocenianych w skali 7-stopniowej. Narzędzie uzyskało wystarczające parametry psychometryczne.

\section{Wyniki badań}

W pierwszym kroku podjętych analiz ustalono poziom zachowań zdrowotnych młodzieży w powiązaniu ze zmiennymi socjodemograficznymi, takimi jak: wiek, płeć i status socjoekonomiczny. Przeprowadzona analiza wariancji 
wskazała, że wiek $(F=2,37 ; \mathrm{p}>0,05)$ ani sytuacja materialna $(F=0,45$; $p>0,05)$ nie różnicują nasilenia ogólnych zachowań zdrowotnych w badanej grupie młodzieży. Natomiast płeć okazała się czynnikiem różnicującym. Średnie zachowań zdrowotnych z uwzględnieniem płci przedstawiono $\mathrm{w}$ tab. 1.

T a b e la 1

Zachowania zdrowotne badanej grupie młodzieży w zależności od płci

\begin{tabular}{|l|c|c|c|c|c|}
\hline \multirow{2}{*}{ Zmienna } & \multicolumn{2}{|c|}{ Chłopcy } & \multicolumn{2}{c|}{ Dziewczęta } & \multirow{2}{*}{\begin{tabular}{c} 
Test $t$ \\
\cline { 2 - 5 }
\end{tabular}} \\
\cline { 2 - 5 } & $M$ & $S D$ & $M$ & $S D$ & $p$ \\
\hline Ogólny wskaźnik zachowań zdrowotnych & 69,72 & 12,14 & 74,01 & 11,4 & $-2,46^{* *}$ \\
\hline Prawidłowe nawyki żywieniowe & 15,44 & 4,22 & 17,99 & 4,44 & $-4,25^{* * *}$ \\
\hline Zachowania profilaktyczne & 15,96 & 4,33 & 18,15 & 4,39 & $-3,90^{* * *}$ \\
\hline Pozytywne nastawienia psychiczne & 19,25 & 4,34 & 19,07 & 4,39 & $0,30 \mathrm{ni}$ \\
\hline Praktyki zdrowotne & 18,6 & 3,81 & 18,74 & 4,02 & $-0,25 \mathrm{ni}$ \\
\hline
\end{tabular}
stycznie.

O b j a śn i e n i a: * $p<0,05 ; * * p<0,01 ; * * * p<0,001$; ni - zależność nieistotna staty-

Średnie wyniki uzyskane przez chłopców i dziewczęta w zakresie ogólnego wskaźnika zachowań zdrowotnych mieszczą się w zakresie wyników niskich (4 sten) (zgodnie z normami podawanymi za: Juczyński, 2001). Ponadto średnie uzyskane w zakresie wskaźników szczegółowych Inwentarza Zachowań Zdrowotnych (prawidłowe nawyki żywieniowe, zachowania profilaktyczne, pozytywne nastawienia psychiczne i praktyki zdrowotne) są w grupie badanych chłopców i dziewcząt nieco niższe od wartości uzyskanych w badaniach różnych grup kobiet i mężczyzn prowadzonych przez Z. Juczyńskiego (2001). Dziewczęta podejmują ogólnie więcej niż chłopcy zachowań korzystnych dla zdrowia $(p<0,05)$, przede wszystkim zaś prezentują bardziej niż chłopcy prozdrowotne nawyki żywieniowe $(p<0,001)$ oraz zachowania profilaktyczne $(p<0,001)$. Uzasadnia to potrzebę prowadzenia dalszych analiz statystycznych, osobno w grupie chłopców i w grupie dziewcząt.

W dalszym etapie analiz obliczono współczynniki korelacji pomiędzy zachowaniami zdrowotnymi a wymiarami osobowości typu D i poczuciem koherencji, osobno w grupie dziewcząt (tab. 2) i chłopców (tab. 3).

$\mathrm{Z}$ danych zawartych $\mathrm{w}$ tab. 2 wynika, że $\mathrm{w}$ grupie dziewcząt istnieje statystycznie istotny związek ogólnego wskaźnika zachowań zdrowotnych ze wszystkimi badanymi wymiarami osobowości. W przypadku negatywnej emocjonalności i hamowania społecznego (wymiary osobowości typu D) jest to związek ujemny, czyli im wyższe nasilenie obu cech, tym niższy wskaźnik korzystnych dla zdrowia zachowań. Wymiary osobowości typu D są także negatywnie powiązane z zachowaniami profilaktycznymi oraz pozytywnymi 
Tabela 2

Współczynniki korelacji pomiędzy zachowaniami zdrowotnymi a wymiarami osobowości typu D i poczuciem koherencji w grupie dziewcząt

\begin{tabular}{|c|c|c|c|c|c|}
\hline Zmienna & $\begin{array}{c}\text { Ogólny } \\
\text { wskaźnik } \\
\text { zachowań } \\
\text { zdrowotnych }\end{array}$ & $\begin{array}{c}\text { Prawidłowe } \\
\text { nawyki } \\
\text { żywieniowe }\end{array}$ & $\begin{array}{c}\text { Zachowania } \\
\text { profilaktyczne }\end{array}$ & $\begin{array}{c}\text { Pozytywne } \\
\text { nastawienia } \\
\text { psychiczne }\end{array}$ & $\begin{array}{c}\text { Praktyki } \\
\text { zdrowotne }\end{array}$ \\
\hline $\begin{array}{c}\text { Negatywna } \\
\text { emocjonalność }\end{array}$ & $-0,52^{* * *}$ & $-0,15$ & $-0,27^{* *}$ & $-0,67 * * *$ & $-0,30^{* *}$ \\
\hline $\begin{array}{c}\text { Hamowanie } \\
\text { społeczne }\end{array}$ & $-0,33^{* * *}$ & $-0,10$ & $-0,26^{* *}$ & $-0,46^{* * *}$ & $-0,09 \mathrm{ni}$ \\
\hline $\begin{array}{c}\text { Poczucie } \\
\text { zrozumiałości }\end{array}$ & $0,43^{* * *}$ & 0,09 & $0,21^{*}$ & $0,49^{* * *}$ & $0,33^{* *}$ \\
\hline $\begin{array}{c}\text { Poczucie } \\
\text { zaradności }\end{array}$ & $0,44^{* * *}$ & 0,02 & $0,26^{* *}$ & $0,56^{* * *}$ & $0,30^{* *}$ \\
\hline $\begin{array}{c}\text { Poczucie } \\
\text { sensowności }\end{array}$ & $0,43 * * *$ & 0,15 & $0,31^{* *}$ & $0,52^{* * *}$ & $0,14 \mathrm{ni}$ \\
\hline $\begin{array}{c}\text { Ogólne poczucie } \\
\text { koherencji }\end{array}$ & $0,50^{* * *}$ & 0,10 & $0,30^{* *}$ & $0,60^{* * *}$ & $0,30^{* *}$ \\
\hline
\end{tabular}

O b j a śn i e n i a: jak do tab. 1 .

T a b e la 3

Współczynniki korelacji pomiędzy zachowaniami zdrowotnymi a wymiarami osobowości typu D i poczuciem koherencji w grupie chłopców

\begin{tabular}{|c|c|c|c|c|c|}
\hline Zmienna & $\begin{array}{c}\text { Ogólny } \\
\text { wskaźnik } \\
\text { zachowań } \\
\text { zdrowotnych }\end{array}$ & $\begin{array}{c}\text { Prawidłowe } \\
\text { nawyki } \\
\text { żywieniowe }\end{array}$ & $\begin{array}{c}\text { Zachowania } \\
\text { profilaktyczne }\end{array}$ & $\begin{array}{c}\text { Pozytywne } \\
\text { nastawienia } \\
\text { psychiczne }\end{array}$ & $\begin{array}{c}\text { Praktyki } \\
\text { zdrowotne }\end{array}$ \\
\hline $\begin{array}{c}\text { Negatywna } \\
\text { emocjonalność }\end{array}$ & $-0,29 * *$ & $-0,01$ & 0,01 & $-0,57^{* * *}$ & $-0,21^{*}$ \\
\hline $\begin{array}{c}\text { Hamowanie } \\
\text { społeczne }\end{array}$ & $-0,13$ & $-0,02$ & $-0,07$ & $-0,23^{*}$ & $-0,04$ \\
\hline $\begin{array}{c}\text { Poczucie } \\
\text { zrozumiałości }\end{array}$ & $0,26^{*}$ & 0,10 & 0,12 & $0,39^{* * *}$ & 0,01 \\
\hline $\begin{array}{c}\text { Poczucie } \\
\text { zaradności }\end{array}$ & 0,20 & 0,01 & 0,03 & $0,40^{* * *}$ & 0,07 \\
\hline $\begin{array}{c}\text { Poczucie } \\
\text { sensowności }\end{array}$ & $0,31^{* *}$ & 0,15 & 0,18 & $0,38^{* * *}$ & 0,12 \\
\hline $\begin{array}{c}\text { Ogólne poczucie } \\
\text { koherencji }\end{array}$ & $0,31^{* *}$ & 0,11 & 0,13 & $0,47^{* * *}$ & 0,08 \\
\hline
\end{tabular}

Objaśnien ia: jak do tab. 1. 
nastawieniami psychicznymi, a negatywna emocjonalność także z praktykami zdrowotnymi. Z kolei zarówno ogólne poczucie koherencji, jak i jego wymiary, czyli poczucie zrozumiałości, sensowności i zaradności, są pozytywnie powiązane $\mathrm{z}$ ogólnym wskaźnikiem zachowań zdrowotnych i ich szczegółowymi kategoriami. Związku wszystkich badanych wymiarów osobowości nie zanotowano jedynie w przypadku prawidłowych nawyków żywieniowych.

Wyniki analizy korelacyjnej w grupie chłopców zawarto w tab. 3. W grupie tej zanotowano mniej istotnych związków badanych wymiarów osobowości z zachowaniami zdrowotnymi w porównaniu $\mathrm{z}$ grupą dziewcząt. Ogólny wskaźnik zachowań zdrowotnych powiązany jest ujemnie z negatywną emocjonalnością, pozytywnie zaś z ogólnym poczuciem koherencji oraz z jego wymiarami - poczuciem zrozumiałości i sensowności. Siła tych związków jest jednak mniejsza niż u dziewcząt. Pozostałe szczegółowe kategorie zachowań zdrowotnych nie są powiązane $\mathrm{z}$ badanymi zmiennymi niezależnymi, za wyjątkiem pozytywnych nastawień psychicznych - ich poziom rośnie wraz ze spadkiem negatywnej emocjonalności i hamowania społecznego oraz ze wzrostem poczucia koherencji i jego wymiarów. Ponadto negatywna emocjonalność wykazuje słaby związek ujemny z praktykami zdrowotnymi.

W kolejnym kroku analiz statystycznych wyznaczono determinanty ogólnego wskaźnika zachowań zdrowotnych. Zastosowano w tym celu regresję wielokrotną metodą krokową postępującą (tab. 4).

Tabela 4

Wyznaczniki ogólnego wskaźnika zachowań zdrowotnych w grupie chłopców i dziewcząt

\begin{tabular}{|l|c|c|c|c|c|c|}
\hline \multicolumn{7}{|c|}{ Chłopcy } \\
\hline & $R^{2}$ & $B$ & SE $B$ & $\beta$ & test $t$ & $p$ \\
\hline Poczucie sensowności & 0,09 & 0,42 & 0,13 & 0,31 & 3,12 & 0,00 \\
\hline Wartość stała & - & 54,97 & 4,87 & - & 11,28 & 0,00 \\
\hline \multicolumn{7}{|c|}{ Dziewczęta } \\
\hline Negatywna emocjonalność & 0,27 & $-0,85$ & 0,13 & $-0,52$ & $-6,40$ & 0,00 \\
\hline Wartość stała & - & 85,31 & 1,99 & - & 42,93 & 0,00 \\
\hline \multicolumn{7}{|c|}{$R=0,52 ; R^{2}=0,27 ; F=41,03 ; d f=1$} \\
\hline
\end{tabular}

O b j a ś n i e n i a: $R^{2}$ - współczynnik wielokrotnej determinacji, $B$ - niestandardowy współczynnik regresji, SE $B$ - błąd standardowy $B, \beta$ - standardowy współczynnik regresji, $R-$ współczynnik korelacji wielokrotnej.

Jak wynika $\mathrm{z}$ tab. 4, w grupie chłopców wyznacznikiem ogólnego wskaźnika zachowań zdrowotnych okazał się wymiar poczucia koherencji - 
poczucie sensowności. Zmienna ta jednak tylko w $9 \%$ odpowiadała za zmienność wariancji wskaźnika zachowań zdrowotnych. Wzrost poczucia sensowności wiąże się ze wzrostem poziomu zachowań prozdrowotnych u chłopców. Z kolei w grupie dziewcząt ustalono, iż negatywna emocjonalność (wymiar osobowości typu D) okazała się jedynym wyznacznikiem zachowań zdrowotnych, określając $27 \%$ wariancji zmiennej zależnej. Im wyższa negatywna emocjonalność, tym niższy poziom korzystnych dla zdrowia zachowań $\mathrm{w}$ grupie dziewcząt.

Ustalono także, jaką rolę pełnią zmienne podmiotowe w odniesieniu do poszczególnych zachowań zdrowotnych. W grupie dziewcząt ustalono predykcyjną rolę poczucia sensowności $\mathrm{w}$ zakresie zachowań profilaktycznych $\left(R^{2}=0,10 ; \beta=0,311\right)$, poczucia zrozumiałości w zakresie praktyk zdrowotnych $\left(R^{2}=0,11 ; \beta=0,33\right)$ oraz negatywnej emocjonalności w zakresie pozytywnych nastawień psychicznych $\left(R^{2}=0,45 ; \beta=-0,67\right)$. Wśród chłopców jedynie negatywna emocjonalność okazała się ujemnym predyktorem pozytywnych nastawień psychicznych $\left(R^{2}=0,33 ; \beta=-0,57\right)$ oraz praktyk zdrowotnych $\left(R^{2}=0,04 ; \beta=-0,21\right)$.

Końcowym etapem analiz było ustalenie modeli przyczynowych zależności między zmiennymi za pomocą metody modelowania równań strukturalnych. Poniżej przedstawiono modele przyczynowych zależności dla wskaźnika ogólnego zachowań zdrowotnych, zbudowane osobno w grupie chłopców i dziewcząt - każdy z nich był najlepszym, jaki można było uzyskać, biorąc pod uwagę kryteria teoretycznej logiczności, ekonomiczności oraz zgodności z przyjętymi miarami empirycznymi. Strzałki oznaczają relacje przyczynowe między zmiennymi. Nieistotne relacje przyczynowe zaznaczono linią przerywaną. Korelacje między zmiennymi zobrazowano za pomocą strzałki w kształcie łuku, zakończonej podwójnym grotem. Wartości umieszczone przy zmiennych egzoi endogenicznych (w owalu) określają wpływ zmiennych latentnych. 


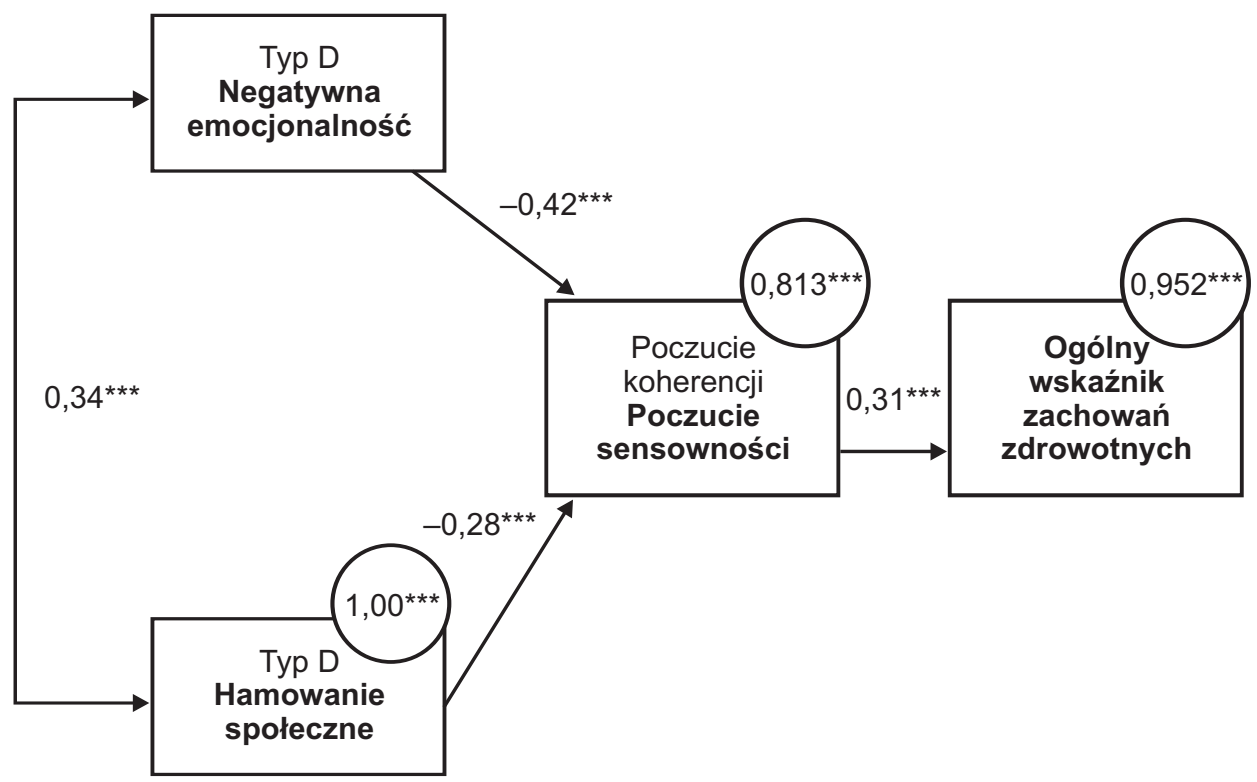

Wartości:

$\chi^{2}=2,67 ; d f=2 ; p=0,26$

GFI Jöreskoga-Sörboma $=0,99$

AGFI Jöreskoga-Sörboma $=0,93$

RMSEA Steigera-Linda $=0,00$

niecentralności McDonalda $=0,95$

Rys. 1. Wyniki analizy ścieżek dla ogólnego wskaźnika zachowań zdrowotnych w grupie chłopców

${ }^{*} p<0,05 ; * * p<0,01 ;{ }^{* * *} p<0,001 ;$ ni - zależność nieistotna statystycznie.

W grupie chłopców bezpośredni wpływ na poziom zachowań zdrowotnych ma wymiar poczucia koherencji - poczucie sensowności (współczynnik ścieżki wynosi 0,$31 ; p<0,01)$. Przekonanie, że życie ma sens, a jego wymagania warte są zaangażowania wzmacnia tendencję do podejmowania zachowań służących zdrowiu przez chłopców.

Nie zanotowano bezpośredniego istotnego wpływu wymiarów osobowości typu D na zmienną zależną. Negatywna emocjonalność oraz hamowanie społeczne maja jednak pośredni wpływ na poziom zachowań zdrowotnych chłopców poprzez oddziaływanie na poczucie sensowności. Oba skorelowane ze sobą wymiary typu D ujemnie oddziałują na poczucie sensowności. 


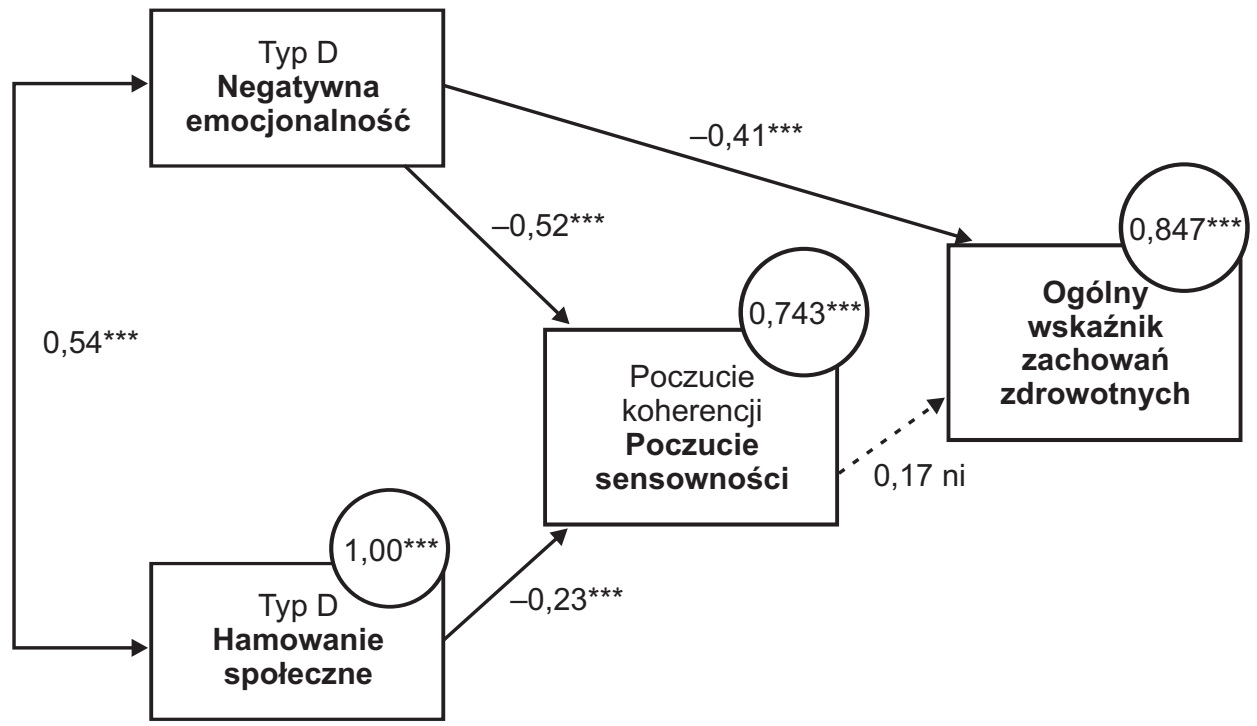

Wartości:
$\chi^{2}=0,167 ; d f=1 ; p=0,67$
GFI Jöreskoga-Sörboma $=0,99$
AGFI Jöreskoga-Sörboma $=0,99$
RMSEA Steigera-Linda $=0,00$
niecentralności McDonalda $=0,98$

Rys. 2. Wyniki analizy ścieżek dla ogólnego wskaźnika zachowań zdrowotnych w grupie dziewcząt

${ }^{*} p<0,05 ; * * p<0,01 ;{ }^{* * *} p<0,001 ;$ ni - zależność nieistotna statystycznie.

W grupie dziewcząt bezpośredni wpływ na poziom podejmowanych zachowań zdrowotnych ma wymiar osobowości typu D - negatywna emocjonalność. Wraz ze wzrostem skłonności do przeżywania negatywnych uczuć maleje poziom korzystnych zachowań zdrowotnych w grupie dziewcząt. Nie zanotowano istotnego statystycznie bezpośredniego wpływu poczucia sensowności na ogólny wskaźnik zachowań zdrowotnych. Ustalono jednak, że tak jak w grupie chłopców, na poziom poczucia sensowności dziewcząt wpływ mają oba wymiary osobowości typu D.

\section{Podsumowanie i dyskusja wyników}

Przeprowadzone badania dowiodły, że zachowania zdrowotne badanej młodzieży są mało korzystne dla zdrowia (według norm: Juczyński, 2001). Dziewczęta $\mathrm{w}$ porównaniu $\mathrm{z}$ chłopcami przejawiają ogólnie więcej zachowań 
prozdrowotnych, a inne zmienne socjodemograficzne (wiek, status socjodemograficzny) nie różnicowały nasilenia zmiennej zależnej. Zastosowane analizy statystyczne prowadzą do następujących wniosków:

- W grupie dziewcząt zanotowano więcej istotnych współczynników korelacji badanych zmiennych osobowościowych z zachowaniami zdrowotnymi niż $\mathrm{w}$ grupie chłopców. Im niższy poziom negatywnej emocjonalności i hamowania społecznego oraz im wyższy poziom poczucia koherencji i jego wymiarów, tym bardziej prozdrowotne zachowania podejmują dziewczęta. U chłopców poziom zachowań zdrowotnych powiązany był $\mathrm{z}$ ogólnym poczuciem koherencji, poczuciem zrozumiałości i sensowności oraz ujemnie $\mathrm{z}$ negatywną emocjonalnością.

- Predyktorem ogólnych zachowań zdrowotnych u chłopców jest poczucie sensowności, u dziewcząt - negatywna emocjonalność.

- Wyniki analiz regresji zostały potwierdzone przez modele przyczynowych zależności między zmiennymi. Na zachowania zdrowotne chłopców bezpośredni wpływ ma poczucie sensowności, u dziewcząt - negatywna emocjonalność. Od wymiarów osobowości typu D zależy także poziom poczucia sensowności, z tym że w grupie dziewcząt jego wpływ na zmienną zależną nie przekroczył kryteriów istotności statystycznej.

Odnosząc uzyskane dane do literatury przedmiotu, należy zaznaczyć, iż w grupach młodzieży notuje się w ostatnich latach niskie wskaźniki wielu zachowań prozdrowotnych (por. Oblacińska, Woynarowska (red.), 2006; Mazur i in., 2007; Sierosławski, 2007; Kolbowska, 2008). Wyżej cytowane badania wskazują także, iż dziewczęta w porównaniu z chłopcami prezentują ogólnie wyższy poziom zachowań korzystnych dla zdrowia, co jest spójne $\mathrm{z}$ ustaleniami płynącymi z badań własnych.

Badania podkreślają także rolę poczucia koherencji w determinowaniu zachowań prozdrowotnych młodych ludzi (por. Zadworna-Ci eślak, Og ińskaB u lik, 2011; Z a d w orn a-C i eślak, Ka flik-P i eróg, 2010; Z a d w ornaCi eślak, Gut o w ska-W y k a, 2009). W grupie młodych dorosłych, w świetle badań, wydaje się, że największe znaczenie wspierające prozdrowotne zachowania ma poczucie sensowności i zaradności ( $\mathrm{Z}$ i a r k o, 2006).

Badania wskazują także na istotne, ujemne powiązania poczucia koherencji i wymiarów osobowości typu D (O g i ńs k a-B u lik, 2009). Osobowość typu D wiąże się także z podejmowaniem zachowań niekorzystnych dla zdrowia, takich jak używanie środków psychoaktywnych, pracoholizm, jedzenioholizm, hazard i zakupoholizm (O g i ńs k a-B u lik, 2009).

Do badań wykorzystujących zmienną osobowości typu D można dodać dane wskazujące na powiązania poziomu stresu (wyższego w przypadku osób typu D) i zachowań zdrowotnych. Dla przykładu, badania przeprowadzone na próbie ponad 12 tysięcy osób dorosłych wskazały, że im wyższy spostrzegany poziom stresu prezentowali badani, tym więcej podejmowali zachowań nie- 
korzystnych dla zdrowia, takich jak dieta wysokotłuszczowa, mały poziom aktywności fizycznej lub palenie papierosów ( $\mathrm{Ng}$, Jeffery, 2003). Nasilenie stresu korelowało negatywnie $\mathrm{z}$ różnymi formami zachowań prozdrowotnych także w badaniach Z. J u c z y ń s k i e g o (1997).

Zachowania ryzykowne i szkodliwe dla zdrowia mogą być sposobem radzenia sobie ze stresem, szczególnie dla osób nieposiadających odpowiednich zasobów pozwalających na konstruktywne radzenie sobie z problemem. Poczucie koherencji uważane jest za metazasób, zarządzający innymi zasobami psychologicznymi, uruchamiający je, gdy są niezbędne lub prowadzący do wycofania się z sytuacji, gdy szanse powodzenia są nieznaczne (H e s z e n, S ę k, 2007). Przeprowadzone badania pokazuja, że cechy osobowości stresowej są czynnikiem ryzyka podejmowania zachowań niekorzystnych dla zdrowia, jednak poczucie koherencji może modyfikować wpływ tych cech osobowości na styl życia. Dzieje się tak przede wszystkim w grupie chłopców, gdyż u dziewcząt to czynniki związane $z$ negatywnymi emocjami mają dominujące znaczenie w kontekście zachowań zdrowotnych. Przypuszczalnie mężczyźni w większym stopniu opracowują poznawczo podejmowane działania (w tym zdrowotne), a szczególnie istotne jest przy tym przekonanie o sensie życia i celowości podejmowania jego wyzwań. Kobiety zaś kierują się w większym zakresie emocjami, a negatywna emocjonalność bezpośrednio ogranicza ich aktywność prozdrowotną. Ponadto powiązania zmiennych osobowościowych z aktywnością zdrowotną okazały się silniejsze u dziewcząt - przypuszczać można, iż u chłopców inne czynniki mogą w większym stopniu wpływać na styl życia, np. związane z wpływem społecznym.

Uzyskane dane warto przełożyć na język praktyki i włączyć w zakres programów profilaktycznych kierowanych do dzieci i młodzieży w celu zapobiegania zachowaniom ryzykownym i promocji zdrowego stylu życia. W programach tych powinno znaleźć się istotne miejsce dla interwencji kształtujących poczucie koherencji, a przede wszystkim przekonanie o sensowności życia. Nie może w nich także zabraknąć oddziaływań kształtujących umiejętności radzenia sobie ze stresem, wyrażania negatywnych emocji i ćwiczeń budujących kompetencje społeczne. Programy promocji zdrowia powinny być prowadzone już na wczesnych etapach edukacji oraz obejmować także rodziców, których rola w kształtowaniu zarówno cech osobowości, jak i zachowań zdrowotnych dzieci jest kluczowa (por. Z a d w or n a-C i eśla k, O g i ńs k a-B u lik, 2011).

\section{Bibliografia}

D e n o 11 e t J. (2005), DS14: Standard assessment of negative affectivity, social inhibition and type D personality, „Psychosomatic Medicine”, 67, 89-97.

Dolińska-Zygmunt G. (2001), Behawioralne wyznaczniki zdrowia - zachowania zdrowotne, [w:] G. Dolińska-Zygmunt (red.), Podstawy psychologii zdrowia, Wydawnictwo UW, Wrocław, 33-70. 
Gniazdowski A. (1990), Zachowania zdrowotne a zdrowie. Podstawowe zależności, [w:] A. G n i a z d o w s k i (red.), Zachowania zdrowotne, Wydawnictwo Instytutu Medycyny Pracy, Łódź, 59-81.

H e s z e n I., S ę k H. (2007), Psychologia zdrowia, Wydawnictwo Naukowe PWN, Warszawa.

Juczyński Z. (1997), Psychologiczne wyznaczniki zachowań zdrowotnych na przykladzie badań osób dorostych, [w:] J. Ł a z o w s k i, G. D o 1 i ń s k a-Z y g m u n t (red.), Ku lepszemu funkcjonowaniu w zdrowiu i chorobie, Wydawnictwo AWF, Wrocław, 258-291.

J u czyński Z. (2001), Narzędzia pomiaru $w$ promocji $i$ psychologii zdrowia, Pracownia Testów Psychologicznych PTP, Warszawa.

J u c z y ń s k i Z., O g i ń s k a-B u 1 i k N. (2009), Narzędzia do pomiaru stresu i radzenia sobie ze stresem, Pracowania Testów Psychologicznych PTP, Warszawa.

K ol b ow sk a A. (2008), Młodziez a substancje psychoaktywne, [w:] Raport końcowy z badań „Młodzież 2008”, Centrum Badania Opinii Społecznej, Warszawa, 3-28, http://www. narkomania.gov.pl/mlodziez2008.pdf, 20.07.2009.

Koniarek J., D udek B., Makowska Z. (1993), Kwestionariusz Orientacji Życiowej. Adaptacja Sense of Coherence Questionnaire (SOC) A. Antonovsky'ego, „Przegląd Psychologiczny”, 36, 491-502.

Łuszczyńska A. (2004), Zmiana zachowań zdrowotnych. Dlaczego dobre chęci nie wystarczaja?, GWP, Gdańsk.

Mazu r J., Woynarowska B., Kołoło H. (2007), Zdrowie subiektywnie, styl życia $i$ środowisko psychospołeczne młodzieży szkolnej w Polsce. Raport techniczny z badań HBSC 2006, Instytut Matki i Dziecka, Warszawa, http://www.imid.med.pl/klient/files/hbsc/ spis\%20tresci.pdf, 11.05.2009.

$\mathrm{Ng}$ D. M., J e f f e r y R. W. (2003), Relationships between perceived stress and health behaviors in a sample of working adults, ,Health Psychology”, 22 (6), 638-642.

Oblacińska A., Woynarowska B. (red.) (2006), Zdrowie subiektywne, zadowolenie $z$ życia i zachowania zdrowotne uczniów szkót ponadgimnazjalnych $w$ Polsce $w$ kontekście czynników psychospolecznych i ekonomicznych. Raport z badań, Instytut Matki i Dziecka, Warszawa, http://www.imid.med.pl/klient/file/zaklad08/zdro_01.pdf, 20.07.2009.

O gińs ka-B ulik N. (2009), Osobowość typu D - teoria i badania, Wydawnictwo WSHE, Łódź.

O g iń s k a-B u lik N. (2010), Zachowania ryzykowne i szkodliwe dla zdrowia, Wydawnictwo AHE, Łódź.

O g iń s k a-B u li k N., J u c z y ń s k i Z. (2008/2010), Osobowość, stres a zdrowie, Wydawnictwo Difin, Warszawa.

P a s i k o w s k i T. (2000), Stres $i$ zdrowie, Wydawnictwo Fundacji Humaniora, Poznań.

S ęk H. (2000), Zdrowie behawioralne, [w:] J. Strela u (red.), Psychologia. Podręcznik akademicki, t. 3, GWP, Gdańsk, 533-553.

S i e ro sławski J. (2007), Używanie alkoholu i narkotyków przez młodzież szkolnq. Raport z ogólnopolskich badan ankietowych zrealizowanych w 2007 roku. Europejski program badań ankietowych $w$ szkołach ESPAD, IPiN, Warszawa, http:/www.narkomania.gov.pl/ epidemiologia.htm, 12.05.2009.

Z a d w or na-C i és la k M., G u to w s k a-W y k a A. (2009), Poczucie koherencji jako zasób sprzyjajacy zachowaniom zdrowotnym młodzieży - przesłanki dla zadań edukacyjnych $i$ wychowawczych, [w:] E. P r z y g od z k a, I. C h m i e l e w s k a (red.), Nauczyciele wobec wyzwań wspótczesności, Wydawnictwo WSHE, Łódź, 107-120.

$\mathrm{Z}$ a d w or na-C i él a k M., K a fl i k-P i e róg M. (2010), Psychospołeczne uwarunkowania zachowań zdrowotnych młodzieży, „Polskie Forum Psychologiczne”, 2, 140-153. 
Z a d w o r n a-C i eśla k M., O g ińs k a-B u li k N. (2011), Podmiotowe i rodzinne uwarunkowania zachowań zdrowotnych młodzieży, Wydawnictwo Difin, Warszawa.

$\mathrm{Z}$ i a r k o M. (2006), Zachowania zdrowotne młodych dorostych-uwarunkowania psychologiczne, Bogucki Wydawnictwo Naukowe, Poznań.

Magdalena Zadworna-Cieślak, Nina Ogińska-Bulik

\section{Type D personality and sense of coherence as predictors of young people's health behaviour}

The aim of this study was to establish whether the dimensions of type D personality negative affectivity and social inhibition, and sense of coherence determine adolescents' health behaviours. The research was conducted on the group of 211 people -96 boys and 115 girls aged $17-19$ years $(\mathrm{M}=18.01, \mathrm{SD}=0.49)$. The research tools were:

- Health Behaviours Inventory (IZZ), author: Z. J u c z y ń s k i (2001);

- The scale to measure the type D personality DS-14, Author: J. Denollet, Polish adaptation of N. Ogińska-Bulik, Z. Juczyński, J. Denollet (J u c z y ń s k i, O g i ń s k a-B u 1 i k, 2009);

- Life Orientation Questionnaire (SOC-29), author: A. Antonovsky, Polish adaptation of J. Kon i are k, B. D u d e k, Z. M a k ow sk a (1993).

In order to indentify variables that determine young people's health related behaviour regression analysis and structural modeling were used. The studies have shown that in the group of boys the direct indicator of health behaviour is the dimension of sense of coherence - a sense of meaningfullness, while in the group of girls - a type D personality dimension, which is negative affectivity.

Keywords: health behaviour, type D personality, sense of coherence (zachowania zdrowotne, osobowość typu D, poczucie koherencji). 